\title{
CENTRO BRASILEIRO DE INFORMAÇÕES SOBRE DROGAS PSICOTRÓPICAS (CONFEN/UNFDAC)
}

O Departamento de Psicobiologia da Escola Paulista de Medicina está consolidando um Centro Brasileiro de Informações sobre Drogas Psicotrópicas, em convênio com o Conselho Federal de Entorpecentes (CONFEN) e com as United Nations Fund for Drug Abuse Control (UNFDAC).

Este Centro reúne, e coloca à disposição do público, dados relativos ao consumo, prevenção, tratamento e repressão ao uso e tráfico de drogas psicotrópicas no Brasil, constituindo-se na primeira iniciativa deste gênero no País.

Um dos serviços que já se encontra em pleno funcionamento é o Banco de Dados da Produção Científica Brasileira sobre o Abuso de Drogas Psicotrópicas. O Banco contém quase 1000 artigos científicos publicados no Brasil, desde o relato clínico da intoxicação de escravos pela planta alucinógena conhecida por "trombeteira", até levantamentos epidemiológicos sobre o uso de bebidas alcoólicas por crianças. As listagens podem ser requisitadas por ano de publicação, autor, estado, revista, droga ou grupo de drogas, população onde o dado foi colhido, conteúdo específico. Através da delimitação destes itens as listagens poderão ser bem específicas ou bem genéricas. A partir da listagem recebida, caso haja interesse, poderão ser obtidas fotocópias dos trabalhos.

As listagens deverão ser solicitadas por carta ao Banco de Dados - Departamento de Psicobiologia/ Escola Paulista de Medicina - Rua Botucatu, 862 - 04023 - São Paulo, SP - Brasil.

Longe de ser completo, pois um grande número de trabalhos científicos brasileiros foi pubiicado em revistas não indexadas, o Banco de Dados aceita e agradece as contribuições que forem feitas (basta enviar cópia do trabalho para o enderenço acima). 